doi:10.18575/msrs.sm.s.16.03 UDK: $616-006.3$ COBISS.RS-ID: 5697816

\section{Korelacija topografske lokalizacije i kliničkih manifestacija u cilju indikacija za hirurško liječenje osteohondroma}

\section{SAŽETAK}

Uvod. Osteohondrom je najčešći benigni tumor kosti koji se javlja u dva oblika, kao sesilni i kao pendularni. Čini do 50\% svih benignih tumora koštanog tkiva, sa dvostrukom predilekcijom ka osobama muškog pola. Prekriven je hrskavičnom kapom različite debljine. Debljina hrskavične kape preko $30 \mathrm{~mm}$ može ukazivati na malignu transformaciju u sekundarni hondrosarkom.

Cilj rada. Utvrditi da li postoji korelacija između epidemioloških karakteristika pacijenata, patohistoloških karateristika, debljine hrskavične kape i biološkog ponašanja tumora.

Ispitanici i metode. Studija presjeka obuhvatila je 37 ispitanika kojima je u periodu od 12 mjeseci, tokom 2014. godine, na Institutu za patologiju Medicinskog fakulteta u Beogradu dijagnostikovan osteohondrom. Pacijentima je deskriptivno analizirana starost, pol, lokalizacija, kliničke manifestacije i dužina trajanja anamneze. Morfometrijski je određivana debljina hrskavične kape na patohistološkim preparatima resekovanih tumora. Od 37 bolesnika kojima je dijagnostikovan osteohondrom, kod $3(8 \%)$ je nastupila maligna alteracija hrskavične kape. Debljina hrskavične kape kod sva tri je bila preko 30 mm, a kretala se od 68-120 mm. Recidiv se javio kod 3 (8\%) pacijenta.

Diskusija. Najveći značaj ove lezije proističe iz činjenice da je to najčešći koštani tumor, velike incidencije, i mogućnost maligne transformacije hrskavične kape u sekundarni hondrosarkom čine ovaj tumor interesantnim za kliničare i patologe.

Zaključak. Širina hrskavične kape u korelaciji sa kliničko-radiološkim parametrima je značajan prediktivni parametar biološkog ponašanja osteohondroma.

Ključne riječi: osteohondrom, debljina hrskavične kape, maligna alteracija

(Scr Med 2016:47:16-20)

\section{SIaviša Kumarac," Jela Aćimović, Marinko Domuzin," Milowad Mamar," Slaviša Mihajlovic}

${ }^{1}$ Traumatološka Klinika UMC Banja Luka

${ }^{2} J Z U$ Institut za javno zdravstvo Republike Srpske, Banja Luka

${ }^{3}$ Dom Zdravlja, Drvar

\section{Kontakt adres a:}

Kunarac Slaviša Ul.Gundulićeva 88 $780 o$ Banja Luka Republika Srpska Mob.+38765991216

E-mail slavisa.kunarac@yahoo.com

Rad primljen: 04.11.2015. Rad prihvaćen: 17.12.2015. 


\section{Uvod}

Tumori se, na osnow biološkog ponašanja, mogu podijeliti na maligne i benigne. Tumori koštanog sistema, u najvećem procentu slučajeva, pripadaju benignim tumorima, od kojih su najčešći osteohondromi (egzostoze), enhondromi, neosifikatni fibromi, gigantocelularni tumori, hondromiksoidni fibromi, te tumori koštanog porijekla osteoblastom, osteoid osteon. ${ }^{1}$

Pacijenti sa ovom vrstom tumora su uglavnom mlađe životne dobi, što dodatno naméce potrebu za delikatnijim pristupon u rješavanju ove vrste patologije. ${ }^{2}$

Osnowni principi dijagnostike svih benignih koštanih neoplazmi su slični i podrazumjevaju klinički fizikalni pregled, manje invazivne imidžing metode u slučaju potrebe, te biopsije suspektne kos̆tane neoplazme. Indikacije za operativnim liječenjem benignił koštanih tumora su, u prvom redu, bol i ošstećenje funkcije datog segmenta lokomotornog aparata, praćenog otokom i kompresivnim sindromom na susjedne neurowaskulame komponente. ${ }^{3}$

Vrste hirurških intervencija za benigne koštane neoplazme su širokog spektra, od intralezionih intervencija, preko en-blok resekcija, do opsežnijih resekcija kosti koji zahtjevaju upotrebu auto i alografta u smislu nadoknade koštanog defekta. ${ }^{4}$

\section{Cilj rada}

Utvrditi da li postoji korelacija izmedu epidemioloskih karakteristika pacijenata, patohistoloskkih karateristika tumora, debljine hrskavične kape i biološkog ponašanja.

\section{Ispitanici i metode}

Studija presjeka je obuhwatila 37 ispitanika kojima je u periodu od 12 meseci, tokom 2014-godine, na Institutu za patologiju Medicinskog fakulteta u Beogradu dijagnostikovan osteohondrom. Pacijentima je deskriptivno analizirana starost, pol, lokalizacija, kliničke manifestacije $\mathrm{i}$ dužina trajanja anamneze.

Tumorsko tkivo dobijeno ekscizionom radikalnom resekcijon je makroskopski analizirano, a iz tumora su uzeti reprezentativni isječci za patohistološku obradu tkiva. Tkivo je dekalcinisano metodom brze dekalcinacije, primjenom $\mathrm{HCI}$ i $\mathrm{H}_{2} \mathrm{SO}_{4}$. Morfometrijska analiza debljine hrskavične kape je rađena na najmanjem uveličanju (40x) mikrometarskom skalon. Hrskavična kapa je mjerena na širini kojaje iskustveno odgovarala maksimalnoj debljini hondralne komponente.

U studiji su učestvovala 37 bolesnika kojima je dijagnostikovan osteohondrom. Prosječna starost je bila $25 \pm 16$ godina. Od ukupnog broja bolesnika, bilo je 24 muška rca (65\%) i 13 žena ( $35 \%$ ). Svi bolesnici koji su učestvovali u studiji su podjeljeni u 5 intervala starosti u opsegu od o-100. Nakon raspodjele je ustanovljeno da najveći broj bolesnika pripada prvom intervalu od o-20 godina, čak 54\%. Najčešća lokalizacija tumora kod bolesnika u паšem istraživanju je femur, a slijede tibija i skapula. Rijetke lokalizacije su os pubis i kalkaneus. U odnosu na tip koštane gradje, $5 \%$ osteohondroma se nalazilo u pljosnatim, a 95\% u cjevastim kostima. Nakon podjele cjelokupnog uzorka bolesnika na djecu i odrasle, sa graničnom vrednošćı od 18 godina, otkriveno je da je pojava osteohondroma u cjevastim kostima češća u populaciji djece (89\%), dok je pojava lezije u pljosnatim kostima češća kod odraslih (15\%). Na cjevastim kostima su lezije uvijek bile lokalizovane u metafizi.(Grafikon 1.)

\section{Grafikon 1. Lokalizacija osteohondroma}

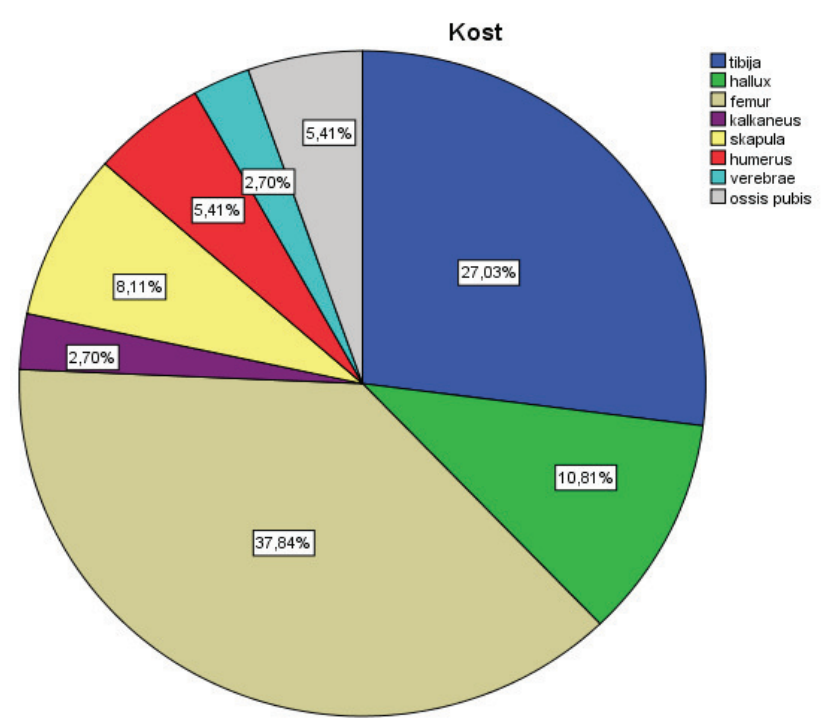

Kliničke manifestacije koje su obuhvaćene ovim istraživanjem su bile bol i kompresija. Osnowni klinički simptom je bio bol, prisutan kod 36/37 pacijenata, a samo 1/37 nije imao bol u anamnestičkim podacima. Kompresivni sindrom je opisan kod $75 \%$ pacijenata.

Dužina trajanja anamneze kretala se od minimalnih 2 do maksimalnih 108 mjeseci, dok je prosječna dužina bila 24 mjeseca. (Tabela 1.) Prosječna dužina trajanja anamneze kod žena bila je 19, a kod muškaraca 27 mjeseci. Bol se kao posljedica pritiska osteohondroma na okolne strukture javio kod 36 (97\%) bolesnika, dok samo jedan bolesnik ne navodi prisustwo bola. U zavisnosti od tipa kosti na kojoj se nalazi osteohondrom, varirala je i klinička slika. Svi bolesnici koji su osteohondrome imali na cjevastim kostima su, u isto vrijeme, imali tegobe u vidu bola, dok je bol osoba koje su osteohondrome inale na pljosnatim kostima bio zastupljen sa oko 80\%. Konpresija mekih tkiva je dokazana kod 9 (24\%) bolesnika, a od toga je lokalizacija osteohondroma isključivo bila na dugim cjevastim kostima. 
Tabela 1. Dužina anamneze

\begin{tabular}{ccc}
\hline Mjeseci & $\mathrm{N}$ & $\%$ \\
\hline 2 & 2 & 5,4 \\
5 & 1 & 2,7 \\
6 & 4 & 10,8 \\
7 & 1 & 2,7 \\
8 & 3 & 8,1 \\
10 & 4 & 10,8 \\
11 & 1 & 2,7 \\
12 & 4 & 10,8 \\
14 & 1 & 2,7 \\
24 & 5 & 13,5 \\
36 & 4 & 10,8 \\
44 & 1 & 2,7 \\
48 & 3 & 8,1 \\
54 & 1 & 2,7 \\
96 & 1 & 2,7 \\
108 & 1 & 2,7 \\
UKUPNO & 37 & 100,0 \\
\hline
\end{tabular}

Od 37 pacijenata kojima je dijagnostikovan osteohondrom, 34 su imala benignu leziju, a 3 znake maligniteta. Od 3 bolesnika kojima je dijagnostikovana maligna transformacija osteohondroma u sekundarni hondrosarkom, 2 su bile osobe ženskog, a 1 osoba muškog pola. Osobama ženskog pola je maligna lezija dijagnostikovana na pubičnim kostima (pljosnate kosti) sredinom četvrte dece nije (35 godina), dok je osobi muškog pola tumor na metafizi tibije (cjevasta kost) otkriven nešto ranije, krajem druge decenije (20 godina). U odnosu na klasifikaciju kostiju skeleta, 2 maligne lezije se nalaze na pljosnatim, a 1 na dugin cjevastim kostima. Dužina anamneze osoba sa malignim lezijama se kretala od 12-48 mjeseci. Svi pacijenti sa malignom pronjenom navode postojanje bola, dok je kompresija bila prisutna samo u slučaju lezije na tibiji, a potpuno izostaje u shıčaju pelvične lokalizacije. Dužina anamneze u našem uzorku varira od 2 mjeseca do 108 mjeseci (9 godina). Kod oba pacijenta je lezija bila lokalizovana na femuru. Kod pacijenata kojima je osteohondrom bio lokalizovan na tibiji, dužina anamneze je bila najkraća i iznosila je $4 \pm 2$ mjeseca.

Uzimajući u obzir debljinu hrskavične kape, bolesnici su intervalno podijeljeni u 3 grupe. Bolesnici sa znacima maligniteta su imali debljinu hrskavične kape preko 68 mm, a sva tri se nalaze u posljednjen intervalu tabele koja pokazuje debljinu hrskavičave kape. (Tabela 2.)

\begin{tabular}{ccc}
\hline Debljina kape $(\mathrm{mm})$ & $\mathrm{N}$ & $\%$ \\
\hline 0-3 & 17 & 45,9 \\
$3,1-10$ & 17 & 45,9 \\
$>10,1$ & 3 & 8,1 \\
UKUPNO & 37 & 100,0 \\
\hline
\end{tabular}

Morbusexostosans je dokazan kod 6 (16\%) bolesnika, a od toga je samo kod jednog bila prisutna kompresija, dok svih 6 navode prisustvo bola. Nijedan bolesnik sa osteohondromatozom nije imao znake maligne alteracije.

Kod 3 (8\%) bolesnika se javio recidiv. Zajednička lokalizacija na metafizama dugih cjevastih kostiju karakterisala je sva tri bolesnika. Svi bolesnici sa recidivon navode $\mathrm{i}$ pojavı bola, dok nijedan nije imao kompresiju.

Debljina hrskavične kape je varirala od 2, 5-5, 1 mm. Nijedan bolesnik sa recidivon nije imao malignu alteraciju osteohondroma, a samo kod jednog je bio prisutan Morbus exostosans. Svi pacijenti kojima je dijagnostikovan sekundarni hondrosarkom (2 osobe muskog i 1 osoba ženskog pola) su bili adulti, a dužina anamneze je iznosila preko 24 mjeseca. Kod 2 pacijenta lezija je bila lokalizovana u aksijalnom skeletu (pubična kost), dok je kod 1 pacijenta tumor zahvatao tibiju.

Sirina kape u ovim tumorima je iznosila od $68 \mathrm{~mm}$ do $120 \mathrm{~mm}$, što se visoko statistički značajno razlikuje od debljine kapa u benignim egzostozama, od o, $6 \mathrm{~mm}$ do 7,8 mm. (Fotografija 1.). Statističkim testovina određivana je i korelacija širine hrskavične kape sa polom, starošćc i dužinon anamneze. Korišćeni testovi nisu pokazali statističku značajnost među navedenim parametrima (Mann-Whitney U za pol: U=103 $\mathrm{p}>0$, 05, Spirmanov koeficijent za uzrast $\rho=0,129 \mathrm{p}>0$, o5 i dužinu anamneze $: \rho=0,215 \mathrm{p}>0,05)$.

Fotografija 1. Detalj sa prethodne mikrofotografije Hrskavična kapa samikrometarskom morfometrijskom skalom. (HE, 100x)

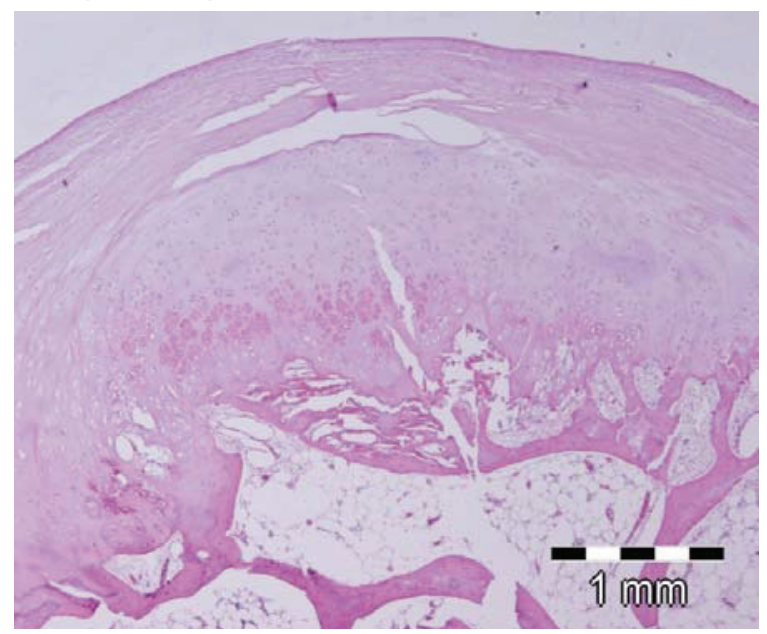




\section{Diskusija}

Osteohondrom je benigni tumor koji, po definiciji Svjetske Zdravstvene Organizacije (WHO), pripada benignim tumorima kosti koji stvaraju hondroidni matriks. ${ }^{5}$ Najweći značaj ove lezije proističe iz činjenice da je to najčešći koštani tumor. Njegova velika incidencija i mogućnost maligne transformacije hrskavične kape u sekundarni hondrosarkom čine ovaj tumor interesantnim za kliničare i patologe. ${ }^{6}$

Mnoga istražvanja su pokazala da je pojava samog tumora najčešća tokom druge decenije života. ${ }^{2-6}$

Većina autora ističe da postoji dvostruka predilekcija bolesnika muškog pola u odnosu na ženski., ${ }^{1,2,4,7}$ Slična raspodjela među polovima je bila zastupljena i u našem uzorku, gde je bilo 13 žena i 24 muškarca.

Osteohondrom se razvija iz kostiju koje nastaju enhondralnom osifikacijon, a najvece biolosko-metaboličke promjene se dešavaju u regiji koljena. Velika incidenca tumora u regiji koljena objašnjava se čestim povredama upravo te regije pri različitim aktivnostima djece $\mathbf{i}$ adolescenata. ${ }^{6}$ Najčešća lokalizacija osteohondroma prema istraživanjima je distalni femur, ${ }^{2}$ dok je u owon istražvanju, pored femura i tibije, zпačajno zastupljena i lokalizacija osteohondroma na skapuli i pelvičnim kostima.Učestalost pojavljivanja tumora na dugim cjevastim kostima (95\%) objašnjava se enhondralnon osifikacijon. ${ }^{2}$ Ovin se objašnjava i veća učestalost osteohondroma cjevastih kostiju u populaciji ljudi kojima epifizne ploče još nisu zatvorene u odnosu na osobe sa zatvorenim epifiznim pločama. ${ }^{2-5}$

Najkraća anamneza u ovoj seriji iznosi 2 mjeseca, a najduža 9 godina. Najkraću anamnezı, $4 \pm 2$ meseca, su imali pacijenti kod kojih je egzostoza bila prisutna na metafizi proksimalne tibije. Kod ovih osoba je tumor bio udružen sa intenzivnim bolon i naglašenim kompresivnim sindromom. Ovakva klinička slika i kratka evolucija tımora su posljedica kompresivnog sindroma na n.peroneus. ${ }^{8}$

Morfometrijska analiza je pokazala da se debljina hrskavične kape značajno razlikuje od lezije do lezije. Minimalna debljina je iznosila samo $0,6 \mathrm{~mm}$, kod pacijenta starog 4 godine, sa lokalizacijom na skapuli i anamnezon od 3 godine.

Većina autora smatra da debljina hrskavične kape veće od $25 \mathrm{~mm}$ povećava šansu za malignu alteraciju osteohondroma. ${ }^{1-8}$ Rezultati naše serije se uklapaju u ova istražvanja. De Andrea i saradnici u svon istraživanju navode da je procenat maligne alteracije kod pacijenata sa solitarnim osteohondromom bio manji od 1\%,7 što nije u korelaciji sa rezultatima ovog istaživanja, gde je od 37 bolesnika, čak kod troje ( $8 \%$ ) došlo do maligne alteracije.

Različiti autori navode recidiv tumora kod 2-4 \% bolesnika, ${ }^{4-8}$ dok je prema rezultatima owog istraživanja, procenat recidiva nešto veći i iznosi 8\%. Gotovo četvorostruko većı učestalost recidiva u owoj studiji možemo objasniti činjenicom da su to lezije koje nisu primarno operisane u referentom centru za koštane tumore, nego u drugim ustanovama, pa su naknadno poslate na reeksciziju.

\section{Zaključak}

Morfonetrijskim određivanjem šrine hrskavične kape moguće je predvidjeti biološko ponašanje egzostoza. Sirina hrskavične kape, u korelaciji sa kliničko-radioloğkim parametrima, je značajan prediktivni parametar biološskog ponašanja osteohondroma.

Lokalizacija promjena između pelvičnog i supraacetabularnog segmenta ima veću incidencu maligne alteracije egzostoze.

Radiološki i patohistološki pokazatelji maligne transformacije su povećanje visine hrskavične kape iznad $2.5 \mathrm{~cm}$ sa promjenom karakteristika hondralnog sloja neoplazme verifikovanih isključivo magnetnom rezonancom.

\section{Reference}

1. Zhang, $F$; Liang J, Guo X, Zhang Y, Wen Y, Li Q, Zhang Z, Ma W, Dai L, Liu X, Yang L, Wang J. (29 August 2013). "Exome sequencing and functional analysis identifies a nowel

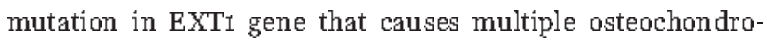
mas.". PLOS ONE 8 (8). Retrieved 25 March 2014. http://dx. doi.org/10.1371/joumal.pone.oo72316

2. Fletcher DM., Unni KK, Martens F.: WHO Classification of Tumours of Soft Tissue and Bone. Pathology \& Genetios. IACP Press. 2013 .

3. Wirganowicz P.Z. Watts $\mathrm{Hg}$. Surgical risik for elective excision of benign exostoses J Pediatr orthop.1997; 17(4) $4455-459$.

http//dx.doi.org/10.1097/00004694-199707000-00008 http//dx.doi.org/10.1097/01241398-199707000-00008 PWid 9364382

4. Nottrott M, Hardes J, Gosheger G, Andreou D, Henrichs M, Streitbuerger A. Benign cartilage tumorg. What should I do with incidental findings?" Unfallchirurg, 2014 Oct;117(10):90514.

http://dx.doi.org/10.1007/s00113-014-2578-3 PWid:25274388

5. Mohindra M, Tiwari A, Gogna P, Thora A. Humeral diaphyseal asteochondroma causing median nerve injury. J Coll Physicians Surg Pak 2014 Mar;24 Suppl 1:S43-5. PMid:24718003 
6. Kwon OS, Kelly JI. Delayed presentation of asteochondroma on the ventral surface of the scapula. Int J Shoulder Surg. 2012 Apr; $; 6(2) \div 61-3$.

http://dx.doi.org/10.4103/0973-6042.96996

PMid:22787335 PMCid:PMC 3391786

7. De Andrea CE, Hogendoorn PC. Epiphyseal growth plate and secondary peripheral chondrosareoma: the neighbours matter. J Pathol. 2012 Jan;226 (2) $) 219-28$. http://dx.doi.org/10.1002/path.3003 PWid:21956842

8. Bernard SA, Murphey MD, Flemming DJ, Kransdorf MJ. Improved differentiation of benign osteochondromas from secondary chondrosarcomas with standardized measurement of cartilage cap at CT and MR imaging. Radiology. 2010 Jum,255 3 ) $857-65$.

http://dx.doi.org/10.1148/radiol.10082120 PMid:20392983

\title{
Correlation of Topographic Localization and Clinical Manifestations for Indications for Surgical Treatment of Osteochondroma
}

\begin{abstract}
Introduction. Osteochondroma is the most common type of benign bone tumor which appears in two forms, sessile and pedunculated. It accounts for $50 \%$ of all benign tumors of bone tissue with a double tendency towards male population. It is covered by cartilage cap of different thickness. The thickness of the cap over $30 \mathrm{~mm}$ can indicate a malign transformation into the secondary chondrosarcoma.
\end{abstract}

Aim of the study. Determine if there is a correlation between epidemic characteristics of the patients, pathohistologic characteristics, thickness of the cartilage cap and biological behavior of the tumor.

Patients and methods.Cross-sectional study included 37 patients which were diagnosed with osteochondroma in the period of 12 months, during the year 2014, at the Institute for pathology of Medical Faculty in Belgrade. The patients' age, sex, localization, clinical manifestation and length of the case history were descriptively determined. The thickness of the cartilage cap was morphometrically determined on pathohistologic devicesof re-sectioned tumors.Out of 37 patients with diagnosed osteochondroma, 3 of them (8\%) had malign alteration of the cartilage cap.The thickness of the cartilage cap in all the 3 of them was over $30 \mathrm{~mm}$, ranging from $68-120 \mathrm{~mm}$. Relapse was found in 3 patients (8\%).

Discussion. The highest importance of this lesion comes from the fact that it is the most common bone tumor with high incidence and possibility for malign transformation of the cartilage cap into secondary chondrosarcoma which makes this tumor interesting for medical staff at the clinic and pathologists.

Conclusion. The width of a cartilage cap, in correlation with clinical and radiology parameters, is a significant predictive parameter of biological behavior of osteochondroma.

Key words: osteochondroma, thickness of the cartilage cap, malign alteration. 